\title{
The Role of Local School Quality in Rural Employment and Population Growth
}

\author{
David L. Barkley, Mark S. Henry, and Shuming Bao*
}

\begin{abstract}
This study investigates the influence of school quality (measured at the high school level) on 1980 to 1990 population and employment change for nonmetropolitan fringe and hinterland census tracts in South Carolina. A Boarnet variation of the Carlino-Mills model is used to examine the interdependence of population and employment change. Local school quality is estimated by scores on standardized tests and students-to-teacher ratios. The model's equations also include variables for local area characteristics identified as determinants of population or employment growth in previous studies (e.g., public service availability and costs, quality of life, labor force characteristics, and access to metro areas). Results of the 2SLS estimation indicate that fringe tracts' population growth was positively related to student test scores, and hinterland tracts population and employment growth were negatively related to student-teacher ratios. Empirical results suggest that local school quality provided a positive influence on rural growth, primarily in terms of residential growth. The role of school quality for employment growth was less clear.
\end{abstract}

\section{INTRODUCTION}

A continuing concern of nonmetropolitan communities is their ability to provide an environment for the sustainable growth of jobs and residents. A potential strategy for providing a conducive environment for growth is improvement in the quality of local public schools. "Good" schools may contribute to future labor quality and enable communities to better compete for industrial activity (Rasmussen 1994). An enhanced role for school quality in industrial recruitment, retention, and expansion efforts results from a greater emphasis by businesses on labor quality and productivity in the new global economy (Berman, Bound and Griliches 1994; Gyan-Baffour and Shaffer 1993; Teixeira and Swain 1991; Beyers, Johnsen, and Stranahan 1987). In addition, school quality is an important component of local quality of life, and school improvements will enhance the attractiveness of a community to potential residents and businesses for whom quality of life is a location factor (Herzog and Schlottman 1991; Boarnet 1994). Thus, regardless of whether "jobs follow people" or "people follow jobs," good schools may contribute to local economic growth and development.

The purpose of this study is to determine if local school quality is related to recent industrial or residential growth in rural areas of South Carolina. School quality is measured at the high school level (including feeder elementary and

Professors of Economic Development, Clemson University, Clemson, South Carolina, and Senior Research Associate, Chinese Data Center, University of Michigan, Ann Arbor, Michigan. Support for this research was provided by the Rural Industries Section, Economic Research Service, U.S. Department of Agriculture, and the Southern Rural Development Center, Starkville, Mississippi. 
middle schools) to reflect differences in "neighborhood" educational offerings rather than at county-wide or school district areas that include several high school attendance zones. A system of simultaneous equations is used to estimate the potential interdependence between population and employment growth and the role of school quality within this system. Finally, the school quality-local growth relationship is estimated separately for rural areas near metropolitan growth centers ("fringe areas") and the more geographically isolated rural communities ("hinterlands"). Bifurcation of the rural areas into fringe and hinterland areas is undertaken to determine if school quality has different influences on population and job growth in rural communities with different residential and employment growth opportunities.

Our findings for rural South Carolina indicate that school quality, as measured by test scores and students-to-teacher ratios, was positively related to local growth after controlling for interdependencies between population and employment change and other determinants of growth. Both population and employment growth were relatively large in hinterland census tracts with lower students-toteacher ratios, and population growth was greatest in fringe census tracts with schools reporting high average test scores. The research upon which these findings are based is organized as follows. First, literature pertaining to the role of school quality in regional growth is reviewed. Second, a Carlino-Mills econometric model is specified and estimated using tract-level data for South Carolina. Third, the empirical results are presented and policy implications proposed.

\section{SCHOOL QUALITY AND RURAL AREA GROWTH}

Population Growth. Mathur and Stein (1993) developed a general equilibrium model of migration to explain how "amenity" improvements could influence the location of households and firms. They demonstrate that amenities stimulate net inmigration of people into a region, with the possible exception of such amenities that are cost augmenting to firms and decrease the inmigration of firms (and "progrowth" households). Examples of empirical research supporting the beneficial role of amenities (defined broadly here to include public infrastructure and services) in area residential growth include studies of: county-level population change (Carlino and Mills 1987); migration decisions of metropolitan residents (Fox, Herzog, and Schlottman 1989; Knapp and White 1992); housing production in metropolitan fringe areas (Kamera 1987), intrametropolitan population growth (Boarnet 1994); and migration to Florida (Assadian 1995). These studies also demonstrate, however, that the influence of amenities on area growth is sensitive to both amenity type and characteristics of the migrants and/or residents.

In this paper, the amenity of interest is local school quality, and regional population growth is measured by the 1980 to 1990 population change at the tract level. We assume that quality local schools are considered a positive attribute by current and potential residents. Yet, maintaining "good" schools is costly and primarily affects families with school age children. Thus the provision of quality schools will have limited (or perhaps perverse) impacts on community residential 
growth if residents' location choices are sensitive to school millage rates or school quality is an important determinant for relatively few rural families.

Employment Growth. The relationship between local school quality and employment growth is less straightforward than that posited for population growth. Good schools benefit area economic growth if enhanced student performance contributes to labor force quality, and as a result, the community is more successful in attracting, nurturing, and retaining businesses. In addition, if good schools attract residents and "jobs follow people," then a quality local school system will enhance employment growth through expanding local markets and labor availability (Knapp and Graves 1989).

Support for a greater role for quality local schools in employment growth is provided in studies of industry location determinants and local business climates. For example, Blair and Premus (1987) note that education is a nontraditional location factor that has been added to many firms' "must-and-want" lists. And Erickson (1987) finds that the availability of skilled labor may be critical to high value-added industries, and he suggests that a high quality education system is generally a key to recruiting and retaining this pool of skilled labor.

The causation chain between local school quality and regional employment growth has, however, potential "kinks." First, good schools will not contribute to a higher quality indigenous labor force if the better educated workers leave the region. Kraybill and Variyan (1993), in a study of the determinants of rural Georgia wage rates, conclude that an individual's educational attainment level is associated with wages received. Renkow (1994) notes, however, that the return to education in rural areas, while positive, is "strikingly" less than the return available in urban areas. Thus investments in rural education can result in significantly higher incomes if the educated are willing to relocate to the cities. Carlin and Ross (1987, p. 22) suggest that if this out-migration is significant "...local investments in education will not be captured in the local work force. Income streams facilitated by improvements on rural elementary and high school education will be realized in urban America and not in rural America. ${ }^{\prime 1}$

Second, good schools and higher educational levels for labor are not valued by all industries due to the correlation between these local attributes and local production costs (e.g., wage and tax rates). Schmenner, Huber, and Cook (1987) find that education is valued by manufacturers characterized by rapid growth and new product engineering. However, the more standardized and routinized the production process, the lower the value placed on education in the workforce.

Third, research on business location and expansion decisions suggests that good schools and educated labor are not sufficient conditions for attracting or

'The good schools-employment growth relationship is further complicated by the possibility that educational attainment levels in communities are functions of local economic opportunities. Broomhall and Johnson (1994) and Stallman and Johnson (1996) found that an increase in the availability of high wage occupations (e.g., managerial) decreased the drop-out rate and increased the percentage of graduates continuing their education. Alternatively, increases in the percentage of local jobs in low wage occupations (e.g., services and trades) increased school dropout rates since such jobs provided rural youth with an incentive to enter the labor market early. Thus current industrial structure, occupational distribution, and employment opportunities provide students with "demonstration effects" pertaining to the potential benefits of education 
retaining industry, even firms valuing skilled labor (Herzog and Schlottmann 1991). Other location factors important to industries include proximity to markets, labor availability, availability and quality of public infrastructure and services, availability of housing, and quality of life. For many firms, numerous locations offer attractive mixes of the firm-specific location factors. Communities with good schools and labor, but deficiencies in other factors, likely will not be selected because alternative locations are available with quality schools and labor as well as acceptable qualities and quantities for other area characteristics important to the location decision. Support for the "no deficiencies" firm location hypothesis is provided in a recent study of manufacturing branch plants' location decisions in Georgia and South Carolina (Barkley and McNamara 1994).

Fourth, only specific types of jobs follow people to an area, thus, a direct relationship between good schools and population growth does not necessarily imply an indirect association between school quality and area employment growth. Thurston and Yezer (1994) find a positive and significant effect of population density gradients on gradients for retail and service sectors, but no significant estimated effects of population decentralization on other industrial sectors.

Education-Rural Development Research. Previous research on the relationship between local school quality and nonmetropolitan economic growth is limited and inconclusive. Two studies of the nonmetro South by the Southern Growth Policies Board (Rosenfeld et al. 1985, 1989) reported positive correlations between county employment growth and various county-level educational characteristics (e.g., adult literacy, scientists and engineers in county, college or university in county). On the other hand, no significant correlations between nonmetro county employment growth and educational attainment levels were found by Schaeffer and Sander (1988) for 548 nonmetro Midwest counties or by Crihfield (1990) for Illinois counties. The above studies used simple correlation analysis to test for association between educational levels and local economic growth; thus no controls were provided for the influences of other area characteristics on employment change.

Two recent studies applied multivariate analysis to test for the role of education on rural economic development, again with conflicting results. McNamara and others (1988) used a single equation logit estimation procedure to test for the association between Virginia communities' successes in attracting new manufacturing plants and 11 community characteristics. Measures of local human capital were math achievement test scores, percentage of adults with high school diplomas, and distance to nearest college. Control variables included community population, manufacturing employment, racial composition, distance to metro area, and wage and tax rates. The Virginia study found a positive relationship between test scores and manufacturing starts but a negative correlation between percentage of adults that are high school graduates and new firm start-ups.

Killian and Parker (1991) used OLS regressions to estimate the effects of average schooling levels on employment growth in nonmetropolitan multi-county commuting zones for the 1970s and 1980s. Commuting zone characteristics included as control variables were: industry mix; earnings per job; age, racial, and 
sexual composition of the labor force; area population; and regional dummy variables. Statistical results indicate that the mix of industries and other local characteristics were more important determinants of growth than were educational levels. Yet, Killian and Parker note that they did not examine the relationship between educational resources (i.e., the quality of local schools) and local employment growth because comprehensive data on local school quality were not available.

The use of single equation regression analysis with control variables is an improvement over simple correlation analysis for estimating the school qualitynonmetropolitan growth relationship. We believe, however, that estimation results may be further improved with two additional modifications. First, econometric modeling of the role of schools in regional growth requires a Carlino-Mills system of equations approach where changes in both population and employment are specified as functions of one another as well as functions of proxies for school quality and other hypothesized determinants of change. Second, school quality should be measured at the level of the local high school (and associated middle and elementary schools) since households (and possibly firms) select locations based on individual school quality rather than county-wide averages.

\section{ECONOMETRIC MODEL}

Changes in a rural community's population and employment are the result of households' and businesses' location decisions, and the location decisions of households and businesses are often interrelated. That is, local characteristics important to households' locations may indirectly influence business locations, and similarly, households' location decisions may be indirectly affected by location factors attractive to businesses. The interdependence of population and employment change may be examined through a two equation simultaneous system as illustrated in equations (1) and (2):

$$
\begin{aligned}
& d P=f\left(P_{t-1} E_{t-1}, d E, R_{t-1}\right) \\
& d E=g\left(E_{t-1}, P_{t-1}, d P, F_{t-1}\right)
\end{aligned}
$$

where:

$d P=P_{t}-P_{t-1}$ where $P$ is a $n \times 1$ vector of population in years $t$ and $t-1$;

$d E=E_{t}-E_{t-1}$ where $E$ is a $n \times 1$ vector of employment in years $t$ and $t-1$;

$R_{t-1}=$ an $n \times j$ matrix of the $j$ residential amenity characteristics in year $t-1$; and

$\mathrm{F}_{\mathrm{t}-1}=$ an $\mathrm{n} \times \mathrm{k}$ matrix of the $\mathrm{k}$ firm amenity characteristics in year $\mathrm{t}-1$;

$\mathrm{n}=$ the number of census tracts.

While the above Carlino-Mills framework provides an empirical structure for reconciling the jobs/people direction of causality issue in the growth processes, it lacks the spatial structural detail necessary for accounting for the role that regional 
linkages may play in local development. Boarnet (1994) provides an extension to the model by explicitly recognizing that labor market areas extend beyond political or census boundaries. He adjusts for this spatial mismatch by incorporating labor market potential variables that are a function of distance from a given area and the number of employees/population in proximate areas. The Boarnet model is summarized in equations (3) and (4):

$$
\begin{aligned}
& d P=f\left(P_{t-1},(I+W) E_{t-1},(I+W) d E, R_{t-1}\right) \\
& d E=g\left(E_{t-1},(I+W) P_{t-1},(I+W) d P, F_{t-1}\right)
\end{aligned}
$$

where:

$\mathrm{I}=$ identity matrix of dimension $\mathrm{n} \times \mathrm{n}$

$\mathrm{W}=\mathrm{a} \mathrm{n} \times \mathrm{n}$ matrix with elements $\mathrm{w}_{\mathrm{ij}}$ where:

$\mathrm{w}_{\mathrm{ij}}=1$ if tract $\mathrm{j}$ is within 30 miles of tract $\mathrm{I}$ (tract centroid to tract centroid), 0 otherwise, except that $\mathrm{w}_{\mathrm{ii}}=0$;

$\mathrm{n}=$ the number of census tracts

$\mathrm{dP}, \mathrm{dE}, \mathrm{P}_{\mathrm{t}-1}, \mathrm{E}_{\mathrm{t}-1}, \mathrm{R}_{\mathrm{t}-1}, \mathrm{~F}_{\mathrm{t}-1}$ are as defined earlier.

The innovation in Boarnet's extension is to use the $\mathrm{W}$ matrix to capture spatially "lagged" effects of employment and population on own population and employment change. In Boarnet's model, estimated using a sample of New Jersey cities, the $\mathrm{W}$ matrix contains weights that decline with distance from a given city. And, it is shown that the changes in city population and employment are adjustments to desired levels (see Henry et al., 1997 for a discussion of the formal model). In our case, we adopt the binary $\mathrm{W}$ matrix to reflect rules of thumb about labor supply availability that are used by the SC Department of Commerce in their marketing efforts.

In sum, tract-level population change is a function of employment and employment change in the area (multi-tract) job market, and tract-level employment change is expressed as a function of population and population change in the area labor market. The use of spatially "lagged" variables recognizes that while the choice of residence and workplace may be jointly determined (e.g., see Waddell 1993), the residence and workplace alternatives are likely to include areas much larger than census tracts.

Equations (3) and (4) typically are estimated using a two-stage least squares technique; however, the reduced form of the system contains spatially lagged dependent variables on the right hand side of the equations (Boarnet 1994). A suggested solution to the spatial autoregressive structure is the use of instrumental variables for $(\mathrm{I}+\mathrm{W}) \mathrm{E},(\mathrm{I}+\mathrm{W}) \mathrm{P},(\mathrm{I}+\mathrm{W}) \mathrm{dE}$, and $(\mathrm{I}+\mathrm{W}) \mathrm{dP}$ in equations $(3)$ and (4). Specifically, Anselin (1988, p. 81-88) proposes that the spatially lagged variables can be instrumented by spatial lags of the estimated values obtained by regressing the endogenous population and employment variables on exogenous 
variables. In this paper, instrumental variables estimators replace the spatially lagged endogenous variables before estimation of the system.

To summarize, we use all exogenous variables (basically beginning period characteristics) in a first stage regression to instrument the endogenous variables, $\mathrm{dP}$ and $\mathrm{dE}$. At this juncture, our procedure is equivalent to any standard 2SLS process. Like other models, errors-in-variables problems are always possible but there does not seem to be a specific serious concern with this form of the CarlinoMills model.

Next, we pre-multiply these estimated values of $\mathrm{dP}$ and $\mathrm{dE}$ by the spatial weight matrix, $(\mathrm{I}+\mathrm{W})$ to construct the tract centered observations on residential zones $(\mathrm{I}+\mathrm{W}) \mathrm{dP}$ and labor zones $(\mathrm{I}+\mathrm{W}) \mathrm{dE}$. At this point, there may be some concern with a few border tracts-those that are contiguous to North Carolina or Georgia since the commuting and residential zones did not incorporate tracts from outside South Carolina. Note that we use border county level employment and population for North Carolina and Georgia as substitutes for the more precise aggregations over census tracts within the thirty-mile commuting zone from border SC tracts. To the extent that the county data are not good proxies for the sets of employment and population that rural South Carolina residents (firms) consider in location at the border of South Carolina, then some errors-in-variables problems may be introduced from the 'border' problem in spatial analysis (see Griffith 1983).

Finally, we have two separate models. One is based on the 224 fringe tract observations; the second model is based on observations for the 267 hinterland tracts. In each model, we estimate the first stage instruments and second stage variables in the same way, though the values for the $(I+W) d P,(I+W) d E,(I+W) E$, and $(\mathrm{I}+\mathrm{W}) \mathrm{P}$ will vary across the two models since the $\mathrm{W}$ matrices are different. However, the same instrumental variable process is used in each case to avoid problems with simultaneity bias. Thus the spatial variables are different but the 2SLS procedure is still needed in each case.

\section{VARIABLE SELECTION AND ESTIMATION}

The two equation system to be estimated initially was specified as shown in equations (5) and (6). Local area characteristics included in the equations are those identified as determinants of population or employment growth in earlier studies of residential and firm locations. Specifically, census tract level residential population change from 1980 to 1990 is hypothesized to be a function of 1980 population and two measures of jobs potential (1980 employment within commuting range of the census tract, weighted by commuting rates; and 1980 to 1990 employment change within commuting range of the census tract, also weighted by commuting rates). Local amenities hypothesized to influence residential location decisions are school quality, crime rates, public service availability and costs, proximity to metro areas, housing availability and quality, access to four-lane highways, racial composition, and income levels and distribution. Tract level employment change from 1980 to 1990 is expressed as a function of 1980 employment and two measures of labor force availability ( 1980 population within 30 miles of a tract and 
1980 to 1990 population change within 30 miles of a tract). Local characteristics hypothesized to be of importance in industrial location decisions are labor quality, public service availability and costs, proximity to metro areas, public infrastructure availability, access to four-lane highways, local quality of life, and school quality. A description of the measures selected to represent area characteristics is provided in Table 1. All variables are at the census tract level unless specified otherwise. ${ }^{2}$

$$
\begin{aligned}
\text { Popch8090 }= & \mathrm{f}(\text { TractPop80, AreaEmp80, AreaEmpCh8090, DistMetro, } \\
& \text { HwDensity, GovExp90, MillRate90, Sewer80, PupTea80, } \\
& \text { TestSc90, Crime90, Income80, Poverty80, Nonwhite, } \\
& \text { Hous7080, PopDen80). }
\end{aligned}
$$

$$
\begin{aligned}
\text { Empch } 8090= & \mathrm{f}(\text { TractEmp80, AreaPop80, AreaPopCh8090, DistMetro, } \\
& \text { HwDensity, GovExp90, MillRate90, WatSew80, PupTea80, } \\
& \text { TestSc90, HSGrad80, College80, Income80, Poverty80, } \\
& \text { Nonwhite, PopDen80). }
\end{aligned}
$$

The model is estimated separately for urban fringe and rural hinterland tracts to determine if the role of school quality in rural population and employment change varies systematically by rural tract population density and distance from the urban core. The urban core is defined as the Census Urbanized Area of the Metropolitan Statistical Area and the surrounding tracts with population densities over 1000 persons per square mile. The urban fringe is defined as the area within a 30-mile distance from the center of the urban core area. The remaining tracts are defined as the rural hinterlands (see Figure 1 for the location of core, fringe, and hinterland tracts within South Carolina Functional Economic Areas). ${ }^{3}$

Population and Employment Change. Population and the selected socioeconomic characteristics were extracted from Census files for 1980 and 1990. Firmlevel employment (in firms with 25 or more employees) was obtained from Dun and Bradstreet files and assigned to tracts (by year established) by address matching with TIGER files if street addresses were provided. County extension offices helped locate firms on county maps when address information was incomplete (e.g., a post office box was given).

The nature of the Dun and Bradstreet data restricts the dependent variable in the employment equation to employment change resulting from the start-up of firms with 25 or more employees. Missing from tract-level employment change are employment fluctuations associated with existing businesses' expansions (con-

\footnotetext{
${ }^{2}$ Ideally, all measures of community amenities should be for 1980 or earlier. Yet reliable tract-level data on crime rates, government expenditures, tax rates, and school test scores were not available until 1990. One could argue, however, that the relative measures did not change greatly over the time period examined. That is, areas with relatively high (low) values in 1990 also were relatively high (low) in 1980 .

${ }^{3}$ Note that since the census tract geography changed between 1980 and 1990, it was necessary to build a common 1980/90 geography. This was accomplished by matching the 1980 and 1990 tracts that had not changed and by using ARCINFO (ESRI 1992) to dissolve 1990 TIGER file boundaries that comprised two or more 1980 tracts. This allowed a consistent 1980/1990 tract geography and census data set with 671 observations (197 core, 224 fringe, 268 hinterland). Other data also were assigned to the appropriate 1980/1990 census tract geography using ARCINFO procedures. In situations where the tract maps and amenity maps did not match, the amenity variable represents a weighted average with weights determined by the share of tract population "experiencing" that amenity.
} 

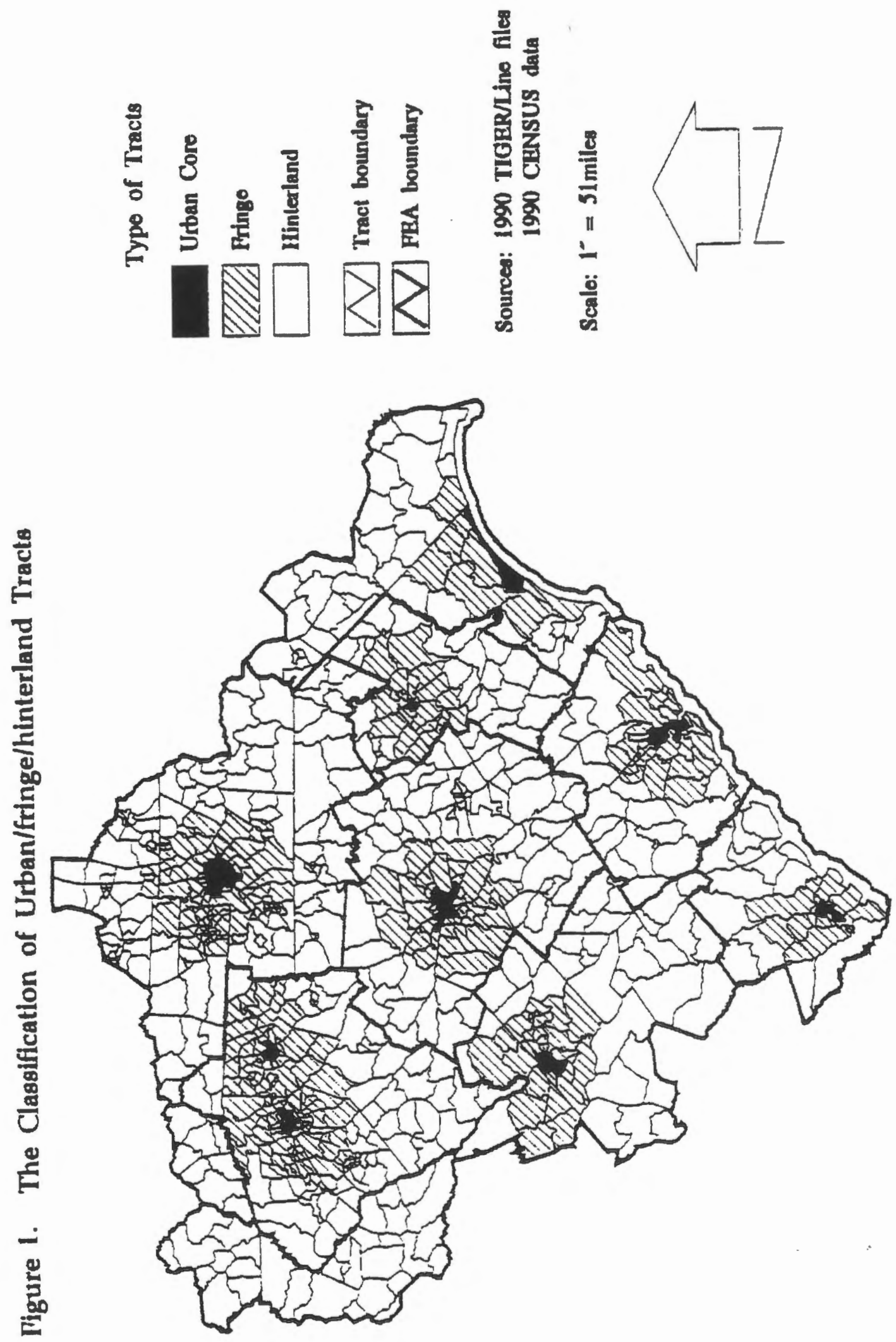
tractions) and business start-ups (closings) for firms with fewer than 25 employees. Thus our model is focused on the relationship between area characteristics and an employment-weighted measure of new firm location decisions. We believe this restricted measure is a reasonable proxy if: (1) employment change in the omitted smaller firms (e.g., retail and service activities) is closely related to population change, and (2) employment in the omitted large, existing firms is primarily a function of firms' characteristics rather than local attributes.

School Quality. Indicators of local school quality used in earlier studies include: expenditures per student, graduation rates, drop-out rates, scores on standardized tests, and pupils-to-teacher ratios (Hanushek 1986, Sander 1993, Betts 1995). For this study we selected test scores (percent of 11th graders scoring above the national average on a standardized test) and pupils-to-teacher ratios for the local high school and feeder elementary and middle schools. ${ }^{4}$ The two selected measures of school quality were assigned to census tracts by overlaying school attendance zones and census tract boundaries. In many cases, an entire rural tract was served by one high school; thus tract and school measures were identical. In situations where a tract contained two or more high school attendance zones, tract educational quality measures were a weighted sum of the local school measures with weights defined as the proportion of tract population served by each school.

Much diversity was evident among South Carolina's rural tracts in terms of test scores and student-to-teacher ratios. The percentage of a school's 11th graders scoring above the national average ranged from seven percent to 70 percent with a mean score of 43 percent. Pupils-to-teacher ratios ranged from 15 to 29 with a mean value of 22. High schools' test scores and pupils-to-teacher ratios were not highly correlated (Pearson correlation coefficient equals .167); thus, the two measures were included jointly in the estimations. The tract-level spatial distributions of the school quality measures are provided in Figures 2 and 3. Tracts are partitioned into top, middle, and bottom thirds by pupils per teacher ratios (Figure 2) and percent of students scoring above the national average on standardized tests (Figure 3). ${ }^{5}$

Local Characteristics. The measures selected to reflect local characteristics and amenities (Table 1) may be highly correlated with one another. Thus we employed principal components analysis (promax factor rotation method), to identify clusters of highly correlated variables and to permit the extraction of a smaller number of relatively independent variables from the original set. ${ }^{6}$ Separate factor analyses were undertaken for the amenity measures associated with: fringe - population, fringe - employment, hinterland-population, and hinterland-employment. Seven factor groupings were identified for each analysis using the criteria where each selected factor has an eigenvalue greater than one

${ }^{4}$ Refer to Card and Krueger $(1992,1996)$ and Word and others (1990) for research demonstrating that class size is a significant determinant of student achievement.

${ }^{5}$ The correlations between the school quality measures and other tract-level characteristics generally were not high. For example, variables with the highest Pearson correlation coefficients with test scores were per capita income (.511) and percent of population 25 or older with some college (.515). Tract-level characteristics with the highest correlations with pupils-to-teacher ratios were percent nonwhite $(-.290)$ and percent in poverty $(-.211)$. 
The Role of Local School Quality in Rural Employment and Population Growth 91

\%

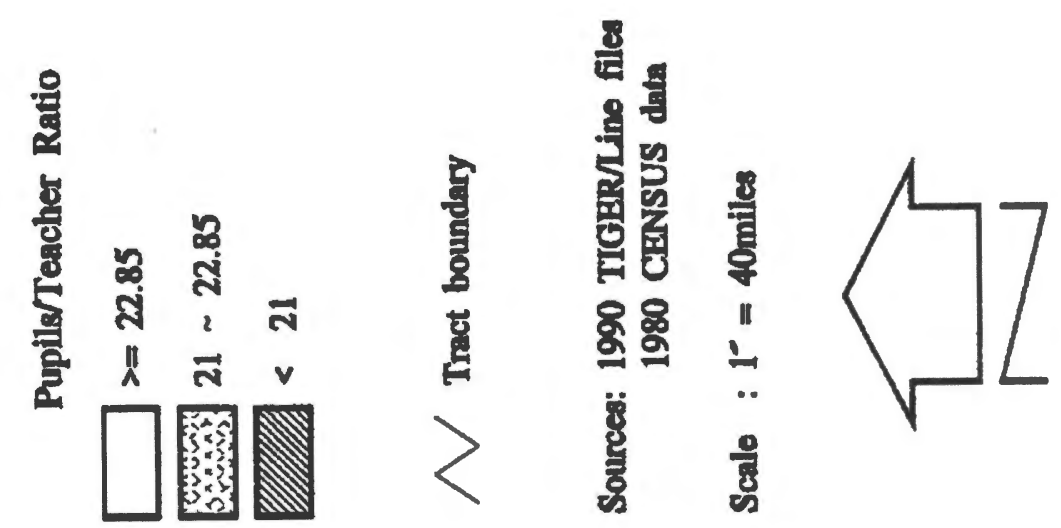

룽

홍

एँ.

s

ปัّ

㟧

क्ष

ัั

돌

訾

i

善

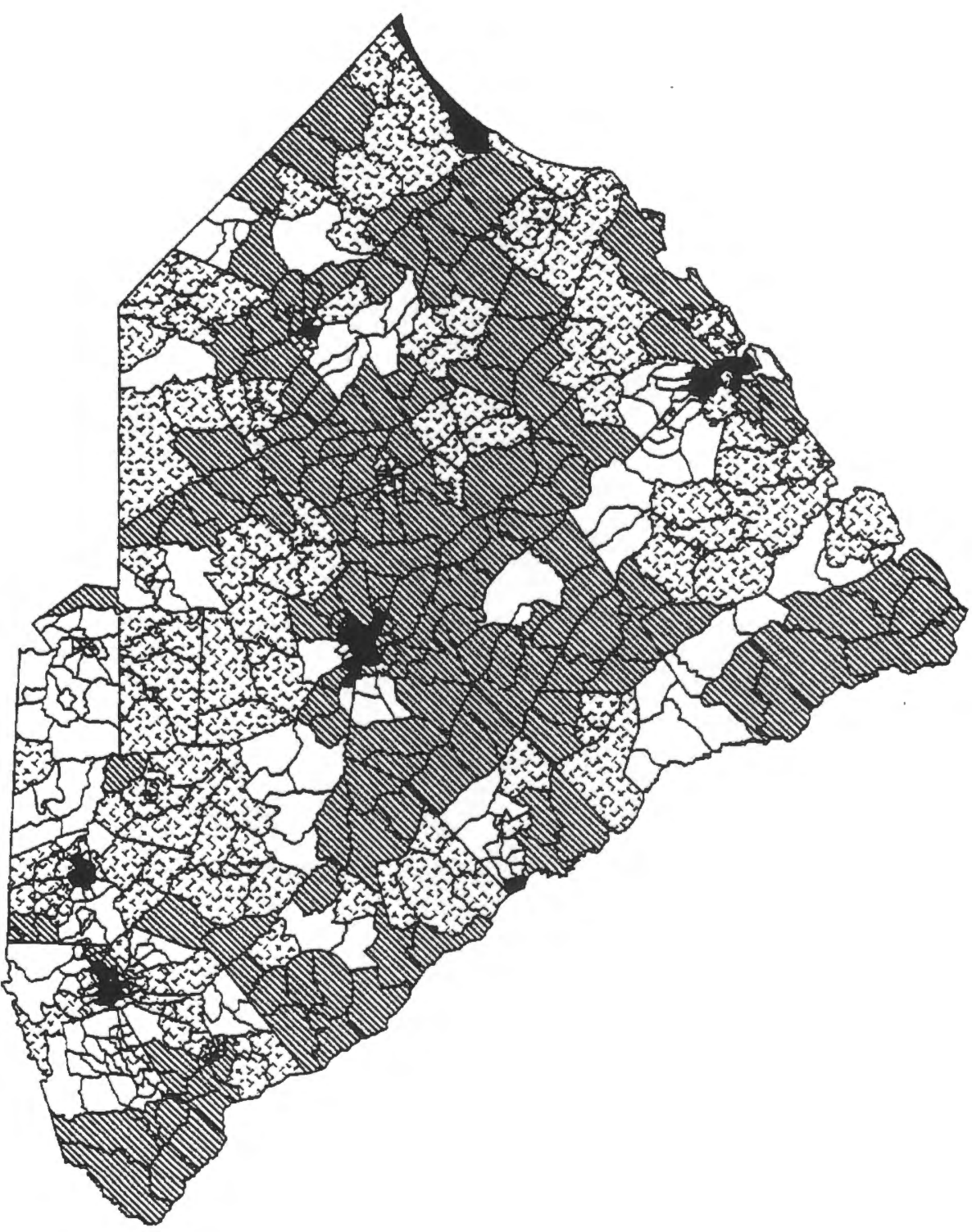




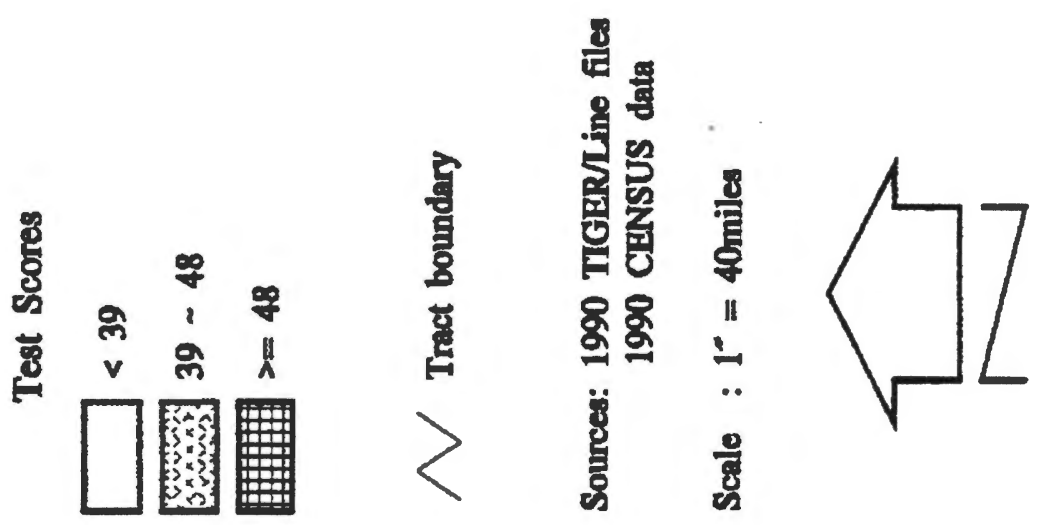

है

U.

हे

क

あ.

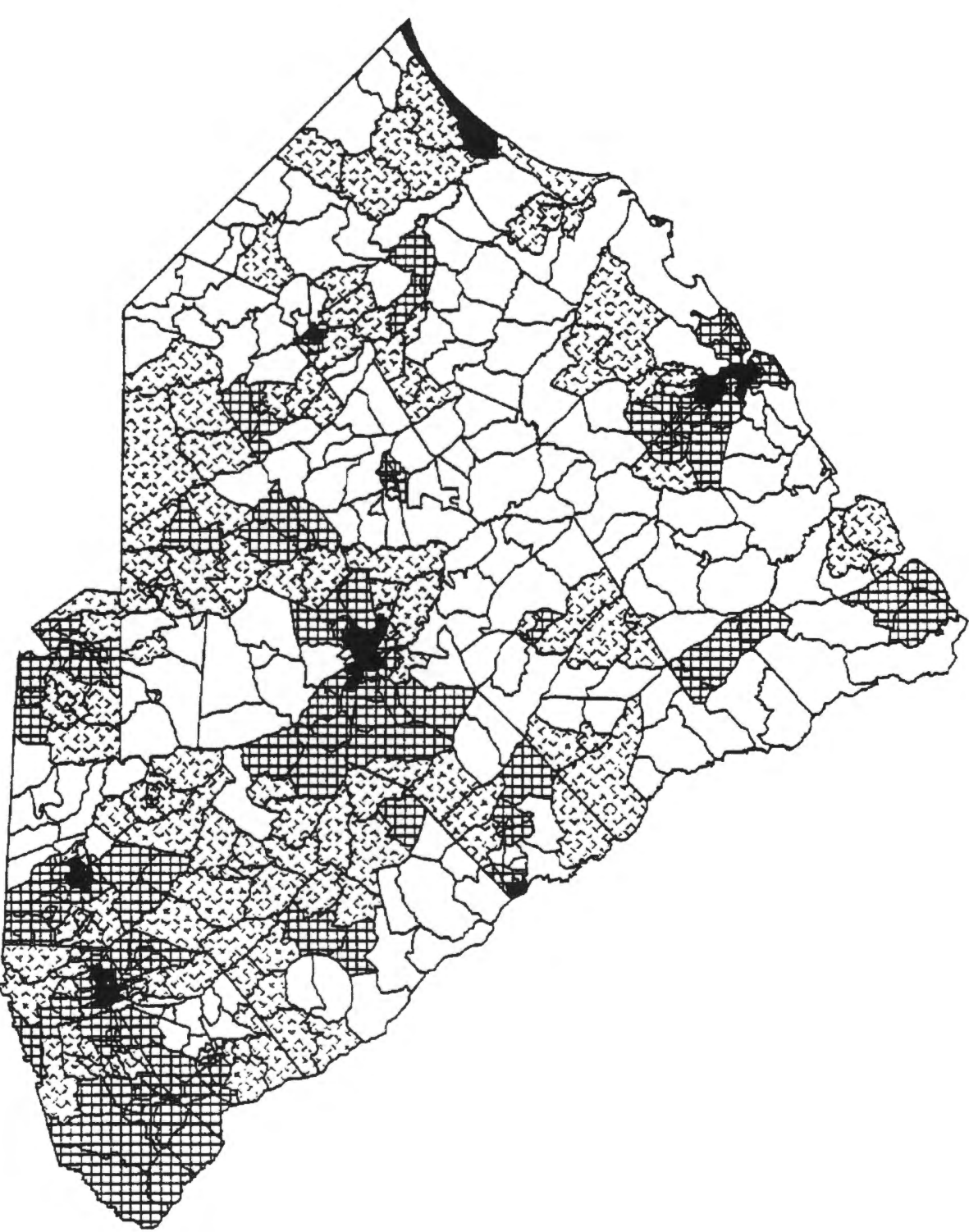


TABLE 1

Variables Selected for Estimating the Determinants of Residential and Firm Location Change

\begin{tabular}{|c|c|}
\hline VARIABLE & DESCRIPTION \\
\hline PopCh8090 & tract population (1990) - tract population (1980) \\
\hline EmpCh8080 & $\begin{array}{l}\text { tract manufacturing employment (1990) - tract manufacturing employment } \\
(1980)\end{array}$ \\
\hline TractPop 80 & tract population (1980) \\
\hline TractEmp80 & tract manufacturing employment (1980) \\
\hline AreaPop80 & 1980 area population (within 30 miles radius of tract centroid) \\
\hline AreaEmp80 & $\begin{array}{l}1980 \text { area manufacturing employment (within commuting range of tract, } \\
\text { weighted by tract-level commuting rates) }\end{array}$ \\
\hline AreaPopCh8090 & area population (1990) - area population (1980) \\
\hline AreaEmpCh8090 & $\begin{array}{l}\text { area manufacturing employment (1990) - area manufacturing employment } \\
(1980)\end{array}$ \\
\hline GovExp90 & $\begin{array}{l}\text { local government expenditures per capita, } 1990 \text { (excluding education } \\
\text { expenditures) }\end{array}$ \\
\hline MillRate90 & aggregate mill rates (city and county excluding school millage), 1990 \\
\hline PupTea80 & students per FTE teacher in high schools, 1980 \\
\hline TestSc90 & eleventh grade scores on standardized tests, 1990 (\% above national average) \\
\hline Income 80 & per capita income, 1980 \\
\hline Poverty 80 & percentage of population below poverty level income, 1980 \\
\hline Crime90 & number of reported crimes per 1000 residents, 1990 \\
\hline Sewer80 & percentage of occupied housing with public sewer utilities, 1980 \\
\hline WatSew80 & water and sewer line density (miles/tract area), 1980 \\
\hline HwDensity & highway density (miles of 4 lane highways/tract area) \\
\hline DistMetro & miles from tract center to nearest metro center, 1980 \\
\hline DistHosp & miles from tract center to nearest full-service hospital, 1980 \\
\hline PopDen80 & population density, 1980 \\
\hline Hous7080 & houses in tract built between 1970 and $1980 / 1980$ total number of houses \\
\hline HSGrad80 & $\begin{array}{l}\text { high school graduates/population aged } 25+\text { (within } 30 \text { mile radius of tract, } \\
\text { 1980) }\end{array}$ \\
\hline College80 & $\begin{array}{l}\text { persons with some college/population aged } 25+\text { (within } 30 \text { mile radius of } \\
\text { tract, 1980) }\end{array}$ \\
\hline Nonwhite & percentage of population nonwhite \\
\hline
\end{tabular}

and no factor-to-factor correlations exceeded .40 (Table 2). For both the fringe and hinterland tracts, per capita incomes, poverty rates, and percent nonwhite were highly correlated. Per capita income was selected among these three measures to represent local income levels and quality of life, and positive relationships between income and population change and income and employment change were hypothesized. In addition, the two labor quality measures (percent high school graduates and percent some college) loaded on one factor. The percentage of the population with some college was selected to represent labor quality and a positive association with employment change was anticipated.

${ }^{6}$ The common factor model can be expressed as follows:

$X i=\alpha_{i l} F_{1}+\alpha_{12} F_{2}+\ldots \alpha_{i j} \quad F_{j}+\ldots .+\alpha_{i m} F_{m}+e_{i} \quad I=1 \ldots . p$

where $X_{i}(I=1 \ldots . . p)$ are the standardized explanatory variables, $F_{i j}(j=1 \ldots . m)$ are the standardized common factors, $\alpha_{i i}$ is the loading (or correlation between $X_{i}$ and $F_{j}$ and $e_{i}$ is the residual term specific to variable $X_{j}$. By employing factor analysis, the original explanatory variables $\left\{X_{i i}\right\}$ can be represented in a smaller set of aggregated factors $\left\{\mathrm{F}_{\mathrm{ji}}\right\}$. Those variables with the high loadings on a factor will be the ones that provide the meaning and interpretation of that factor.

For initial factor extraction, there are several methods available in SAS program. These include Principal Components analysis, Alpha analysis, Maximum-likelihood analysis, Harris component analysis and Image analysis. The cutoff points for the choice of the number of factors can be decided according to the percentage of the total variance explained by the selected factors or the associated eigenvalue that corresponds to the equivalent number of original variables which the factor represents. Ideally, each original variable has a high loading on only one factor and small loading on all other factors. When the factor interpretations are not clear-cut, further factor rotations (such as Varimax, Quartimax, Orthomax and Promax) can be applied to initially extracted factors to redefine the factors in order to make sharper distinctions in the meaning of the factors. 
TABLE 2

Factor Analysis Groupings of Census Tract Characteristics, Fringe and Hinterland Tracts, South Carolina

\begin{tabular}{|c|c|c|c|c|}
\hline & Fringe Tracts & Hinterland $\mathrm{Tr}$ & & \\
\hline Factor Groupings & Population & Employment & Population & Employment \\
\hline FACTOR 1 & $\begin{array}{l}\text { Income } 80^{*} \\
\text { Poverty } 80 \\
\text { Nonwhite }\end{array}$ & $\begin{array}{l}\text { Income } 80^{*} \\
\text { Poverty } 80 \\
\text { Nonwhite }\end{array}$ & $\begin{array}{l}\text { Income } 80^{*} \\
\text { Poverty } 80 \\
\text { Nonwhite }\end{array}$ & $\begin{array}{l}\text { Income } 80^{*} \\
\text { Poverty } 80 \\
\text { Nonwhite }\end{array}$ \\
\hline FACTOR 2 & $\begin{array}{l}\text { GovExp } 90 \\
\text { MillRate } 90^{*} \\
\text { Sewer } 80 \\
\text { Crime } 90 \\
\text { PopDen } 80\end{array}$ & $\begin{array}{l}\text { GovExp } 90 \\
\text { MillRate } 90^{*} \\
\text { WatSew } 80 \\
\text { PopDen } 80\end{array}$ & $\begin{array}{l}\text { GovExp } 90 \\
\text { MillRate } 90^{*} \\
\text { Sewer } 80\end{array}$ & $\begin{array}{l}\text { GovExp } 90 \\
\text { MillRate 90* }\end{array}$ \\
\hline FACTOR 3 & DistMetro & $\begin{array}{l}\text { HS Grad } 80 \\
\text { College } 80^{*}\end{array}$ & $\begin{array}{l}\text { PopDen } 80^{*} \\
\text { HwDensity } \\
\text { Crime } 90\end{array}$ & $\begin{array}{l}\text { PopDen } 80^{*} \\
\text { HwDensity } \\
\text { WatSew } 80\end{array}$ \\
\hline FACTOR 4 & Hous 7080 & DistMetro & DistMetro & $\begin{array}{l}\text { HSGrad } 80 \\
\text { College } 80^{*}\end{array}$ \\
\hline FACTOR 5 & HwDensity & HwDensity & Hous 7080 & DistMetro \\
\hline FACTOR 6 & PupTea 80 & PupTea 80 & PupTea 80 & PupTea 80 \\
\hline FACTOR 7 & TestSC 90 & TestSC 90 & TestSC 90 & TestSC 90 \\
\hline
\end{tabular}

"Variable selected to represent the factor grouping.

Among fringe tracts, government expenditures per capita, tax rates, percent houses on sewers, density of water and sewer lines, crime rates, and population density were highly correlated. The more densely populated tracts tended to be incorporated areas with both city and county services and the accompanying city and county taxes. Local tax rates were selected to represent areal differences in public services availability and costs. No association between millage rates and population or employment change was hypothesized since services availability favors growth but the attendant higher taxes discourage new residents and firms.

The remaining amenity measures (distance to metro area, miles of four-lane highways, quality of the housing stock, pupils-to-teacher ratio, student test scores) exhibited high loadings on individual factors, or low to moderate loadings on multiple factors. All five characteristics were included in the estimations. Of these measures, high school test scores, access to four-lane highways, and housing quality were hypothesized to be positively related to population and employment change. A negative relationship with tract-level growth was predicted for pupilsto-teacher ratio and distance to nearest metro area.

Results of the hinterland factor analysis were similar to the fringe tract results with one exception. Among hinterland tracts, access to four-lane roads and population density were highly correlated. Population density was selected to represent these two amenity measures, and a positive association with tract growth was hypothesized.

Results. Estimation results for the simultaneous systems are provided in Tables 3 (fringe tracts) and 4 (hinterland tracts). The findings support the hypothesis that changes in population and employment are interrelated. Specifically, population change in fringe tracts was positively related to the base year population, 
employment within 30 miles, tract per capita income, distance from the core, and quality of housing stock. Population changes were relatively low in areas with rapid employment growth during the period, a finding consistent with Waddell's (1993) research indicating that suburbanization is discouraged by growth in manufacturing and other industries. Fringe employment change was higher for tracts with larger 1980 employment bases and tracts proximate to four-lane highways.

TABLE 3

Results of the Boarnet Model Estimation, Fringe Tracts, South Carolina

\begin{tabular}{|c|c|c|c|c|}
\hline \multirow[b]{2}{*}{ Variables } & \multicolumn{2}{|c|}{ Population Equation } & \multicolumn{2}{|c|}{ Employment Equation } \\
\hline & Coefficients & $t$-values ${ }^{a}$ & Coefficients & t-values \\
\hline Constant & -7279.240 & $-5.852^{* * *}$ & 232.903 & .583 \\
\hline TractPop 80 & .258 & $7.709^{* * *}$ & & \\
\hline TractEmp80 & & & .124 & $4.656^{* * *}$ \\
\hline AreaPopCh8090b & & & .002 & .719 \\
\hline AreaEmpCh8090c & -.023 & $-1.979 * * *$ & & \\
\hline AreaPop80 & & & .000 & .078 \\
\hline AreaEmp80 & .018 & $2.240^{* * *}$ & & \\
\hline Housing Quality & 63.844 & $7.535^{* * *}$ & & \\
\hline Per Capita Income & .139 & $1.612^{*}$ & .008 & .316 \\
\hline Public Services/Taxes & .271 & 0.62 & .056 & .050 \\
\hline Area Labor Quality & & & 2.692 & .777 \\
\hline Student to Teacher Ratio & 55.181 & 1.174 & -14.626 & -1.031 \\
\hline 11th GradeTest Scores & 25.926 & $2.209^{* * *}$ & 1.301 & .335 \\
\hline Dist to Metro & 57.246 & $2.537^{* * *}$ & -7.148 & -.992 \\
\hline 4-Lane Roads & 211.064 & .525 & 204.637 & $1.729 *$ \\
\hline Adj R2 & .475 & & .152 & \\
\hline $\mathrm{N}$ & 224 & & 224 & \\
\hline F Value & 21.210 & & 4.997 & \\
\hline
\end{tabular}

In this and the following table, ${ }^{* * *}$ indicates significant at the .01 level, ${ }^{* *}$ significant at the .05 level, and * significant at the .10 level.

${ }^{b}$ Area population refers to population in the tract plus population in tracts within 30 miles (centroid to centroid) of the tract.

${ }^{\mathrm{c}}$ Area employment is the tract employment plus employment within commuting range of the tract, weighted by tract-level commuting rates.

Population change in hinterland tracts was positively related to 1980 population, 1980-1990 employment change in the area, per capita income, and housing quality. Hinterland tract population change was negatively correlated with 1980 area employment and high public expenditures/tax combinations. Employment change in the hinterlands was positively associated with 1980 tract employment, area population, population density, and per capita income.

Of principal interest to this study is the role of school quality on tract-level population and employment changes. Among the fringe census tracts (tracts within 30 miles of an urbanized area), change in employment was negatively related to schools' pupils-to-teacher ratios and positively related to test scores, but the estimated coefficients were not statistically significant. On the other hand, fringe tract population change was positively and significantly related to the percentage of students scoring above the national average on standardized tests. Thus if households associated high student achievements with good schools, local school quality had a positive influence on future residential growth. 
TABLE 4

Results of the Boarnet Model Estimation, Hinterland Tracts, South Carolina

\begin{tabular}{|c|c|c|c|c|}
\hline \multirow[b]{2}{*}{ Variables } & \multicolumn{2}{|c|}{ Population Equation } & \multicolumn{2}{|c|}{ Employment Equation } \\
\hline & Coefficients & $\overline{t \text {-values }}$ & Coefficients & $\mathrm{t}$-values \\
\hline Constant & -1457.029 & $-2.232^{* * *}$ & -112.231 & -.773 \\
\hline TractPop80 & .053 & $4.035^{* * *}$ & & \\
\hline TractEmp80 & & & 142 & $12.429^{* * *}$ \\
\hline AreaPopCh8090a & & & .001 & .493 \\
\hline AreaEmpCh8090 & 197 & $3.281^{* * *}$ & & \\
\hline AreaPop80 & & & .001 & $1.585^{*}$ \\
\hline AreaEmp80 & -.073 & $-4.055^{* * *}$ & & \\
\hline PublicServices/ Taxes & -3.145 & $-1.703^{* *}$ & .352 & .787 \\
\hline Per Capita Income & .359 & $7.497^{* * *}$ & .040 & $3.409^{* * *}$ \\
\hline Population Density & .083 & .682 & .042 & $1.444^{*}$ \\
\hline Dist to Metro & -4.040 & -.882 & 1.420 & 1.244 \\
\hline Area Labor Quality & & & -.256 & -.183 \\
\hline Student to Teacher Ratio & -48.211 & $-2.357^{* * *}$ & -8.983 & $-1.756^{* *}$ \\
\hline 11th Grade Test Scores & 5.629 & .955 & -.223 & -.156 \\
\hline Housing Quality & 34.658 & $6.067^{* * *}$ & & \\
\hline Adj R2 & .405 & & .467 & \\
\hline $\mathrm{N}$ & 267 & & 267 & \\
\hline F Value & 19.151 & & 22.585 & \\
\hline
\end{tabular}

a Refer to Table 3 for definitions of area population and employment.

The role of school quality in area growth is less ambiguous for the more geographically-isolated hinterland tracts. Both population and employment growth were negatively (and significantly) related to local schools' pupils-toteacher ratios. Residential and job growth were slowest in tracts with relatively low investments in schools' faculty. In addition, hinterland tract population change was positively, but not significantly, related to local high school test scores. Yet high school test scores were moderately correlated with per capita incomes (correlation coefficient of .41) for the hinterland tracts, and hinterland per capita income levels were an important determinant of tract population growth. If individuals associated higher income communities with better schools (not necessarily a correct assumption for rural South Carolina), then the influence of school quality on residential growth may be captured by the income variable. ${ }^{7}$

In summary, quality local schools, as measured by test scores and studentsto-teacher ratios, provided a positive influence on rural growth. This influence on area growth was evident primarily in terms of the positive relationship between school quality and population change in both fringe and hinterland tracts. The role of school quality for local employment growth was less clear. Hinterland employment growth was more rapid in areas with lower student-teacher ratios, and good schools indirectly stimulated hinterland employment through their positive influence on area population. However, no significant direct or indirect relationships between school quality and employment change were detected for fringe tracts.

The hinterland and fringe models also were estimated with pupils-to-teacher ratios and test scores used individually as a measure of school quality. The coefficients and levels of significance for all the variables differed little from the reported estimations. In addition, the models were estimated with employment change measured for manufacturing firms only. Again, the results (signs and significance levels of coefficients) differed little from the reported estimations. 
Our findings of a positive relationship between school quality and hinterland residential and employment growth are consistent with Waddell's (1993) observation that residence and workplace are jointly determined. The absence of a similar finding for fringe tracts may result from the much smaller geographic size of fringe tracts compared to the less densely populated hinterland tracts. That is, fringe households may jointly determine their residence and workplace, but it is less likely (relative to hinterland tracts) that residence and workplace will be in the same tract because of the smaller fringe tract size. Thus our findings for fringe tracts are not necessarily inconsistent with the joint choice of places to reside and work.

The results of our analysis provide insights into the conflicting findings of earlier school quality-rural development research. First, estimations of the relationship between school quality and economic development appear sensitive to the level of aggregation selected. A stronger role for school quality is detected in our tract-level study than in earlier research based on county-level or commutingzone-level data. Greater geographic specificity permits better identification of school quality differences within rural areas. Second, local residential and employment growth are influenced by factors other than the quality of the local public school system. Studies not accounting for other determinants of growth are inappropriately specified, and their conclusions regarding the role of schools and education are highly suspect. Finally, our findings indicate that school quality affects community growth primarily through its influence on residential rather than business location decisions. Earlier research efforts measuring rural growth by changes in number of firms or employees miss the indirect benefits schools provide to businesses through their influence on residential population change. It is not surprising, therefore, that schools were concluded to have little or no role in area growth where measures of growth are restricted to changes in the number of firms or employees.

\section{SUMMARY AND IMPLICATIONS}

The purpose of this study was to determine if local residential and job growth were influenced by local school quality after controlling for interdependencies between population and employment change and other potential determinants of change. Our findings for rural South Carolina indicate that school quality does matter, especially in the more geographically isolated rural tracts. Both population and employment growth were relatively large in hinterland tracts with lower students-to-teacher ratios, and population growth was greatest in fringe tracts with schools reporting high average test scores.

Our findings for rural tracts indicate that investments in local schools is a promising strategy for local growth. Yet the results also demonstrate that local growth propensities were influenced by other factors. Population and employment change were most rapid in areas with requisite public services and infrastructure, low taxes relative to public expenditures, and high quality of life and housing quality. In our opinion, the marginal benefits of school quality improvements on local growth will be reduced if the community lacks the desired public 
services, quality of life, and labor market characteristics. Similarly, improvements in these non-school quality attributes may have only limited impacts if local school quality is relatively poor. It is likely that rural location alternatives are sufficiently numerous that prospective households and firms do not have to settle for communities with serious deficiencies in any relevant amenities.

In conclusion, within the ongoing debate of "schools are important" versus "schools are not important," we straddle the issue with an "it depends." The importance of school quality as a rural economic development strategy depends on the location and characteristics of the community. Improvements in school quality will enhance community growth prospects for those communities with the appropriate mix of other amenities. We should note that these findings are based on data for rural areas in a state whose rural development programs focus on the relatively low-skilled, standardized manufacturing. The development benefits of school improvements may be even more pronounced in areas where more skillintensive manufacturing is recruited. 


\section{APPENDIX TABLE A}

Rotated Factor Patterns for Population and Employment Amenities, Fringe and Hinterland Tracts, South Carolina

\begin{tabular}{lccccrr}
\hline \multicolumn{7}{c}{ A-1 Fringe - Population } \\
\hline Amenity & Factor 1 & Factor 2 & Factor 3 & Factor 4 & Factor 5 & Factor 6 \\
\hline DistMetro & .140 & -.152 & -.149 & .109 & -.118 & .846 \\
HwDensity & -.018 & -.023 & .036 & -.008 & .947 & -.112 \\
GovExp90 & .769 & -.007 & .180 & .047 & .154 & .254 \\
MillRate90 & .817 & .091 & .141 & .032 & -.071 & .131 \\
Sewer80 & .215 & .134 & .651 & .086 & .189 & -.051 \\
PupTea80 & -.068 & .126 & .117 & .962 & -.007 & .102 \\
TestSc90 & .015 & .617 & .456 & .066 & -.153 & -.213 \\
Income80 & .237 & .943 & -.133 & -.046 & .053 & .029 \\
Poverty80 & .096 & .875 & .208 & -.183 & -.004 & .107 \\
Crime90 & .851 & .213 & .104 & -.247 & -.072 & -.058 \\
Hous7080 & -.661 &. .354 & .209 & -.208 & .024 & .352 \\
PopDen80 & .179 & -.353 & .775 & .041 & -.058 & -.081 \\
\hline
\end{tabular}

A-2 Fringe - Employment

\begin{tabular}{lcccccr}
\hline Amenity & Factor 1 & Factor 2 & Factor 3 & Factor 4 & Factor 5 & Factor 6 \\
\hline DistMetro & .018 & .034 & -.035 & -.018 & .051 & .985 \\
HwDensity & -.003 & -.063 & .072 & .982 & -.040 & -.016 \\
GovExp90 & .942 & -.142 & .066 & .059 & -.024 & .109 \\
MillRate90 & .962 & -.073 & .108 & -.256 & -.073 & -.054 \\
WatSew80 & .851 & .020 & -.011 & .169 & -.008 & -.011 \\
HSGrad80 & -.142 & .965 & .081 & -.022 & -.107 & .035 \\
College80 & .032 & .930 & .123 & -.060 & -.012 & .020 \\
PupTea80 & -.037 & -.084 & .082 & -.041 & .984 & .049 \\
TestSc90 & .149 & .343 & .481 & .041 & .170 & -.123 \\
Income90 & .094 & .254 & .831 & .055 & -.064 & .087 \\
Poverty80 & .119 & .019 & -.864 & -.018 & -.101 & .083 \\
PopDen80 & .484 & .368 & -.466 & .080 & .171 & -.071 \\
\hline
\end{tabular}

A-3 Hinterland - Population

\begin{tabular}{lcccccc}
\hline Amenity & Factor 1 & Factor 2 & Factor 3 & Factor 4 & Factor 5 & Factor 6 \\
\hline DistMetro & .001 & .081 & .050 & .997 & .050 & -.021 \\
HwDensity & -.209 & .929 & -.035 & .214 & -.079 & .043 \\
GovExp90 & 842 & -.052 & .150 & -.088 & -.011 & -.036 \\
MillRate90 & .889 & -.116 & -.131 & .056 & .000 & .036 \\
Sewer80 & .690 & .364 & .153 & .080 & -.183 & .008 \\
PupTea80 & .004 & .036 & .021 & -.024 & -.028 & .984 \\
TestSc90 & -.256 & .121 & .446 & -.226 & -.524 & -.002 \\
Income80 & .180 & .086 & .948 & .026 & .150 & -.049 \\
Poverty80 & .015 & .204 & -.897 & -.070 & .025 & -.078 \\
Crime90 & .148 & .736 & -.011 & -.235 & .353 & .039 \\
Hous7080 & -.386 & .034 & .165 & -.016 & .758 & -.041 \\
PopDen80 & .236 & .632 & -.112 & -.068 & -.262 & -.063 \\
\hline
\end{tabular}

A-4 Hinterland - Employment

\begin{tabular}{lcccccr}
\hline Amenity & Factor 1 & Factor 2 & Factor 3 & Factor 4 & Factor 5 & Factor 6 \\
\hline DistMetro & .122 & -.043 & -.080 & -.049 & .981 & -.073 \\
HwDensity & .853 & .132 & .022 & -.201 & .229 & .156 \\
GovExp90 & .119 & -.002 & -.178 & .824 & -.086 & -.021 \\
MillRate90 & .003 & .051 & .120 & .872 & .093 & .059 \\
WatSew80 & .855 & -.094 & .043 & .232 & -.065 & -.039 \\
HSGrad80 & -.040 & .955 & -.002 & -.029 & -.039 & -.017 \\
College80 & .022 & .945 & -.005 & .071 & -.018 & -.012 \\
PupTea80 & .033 & -.029 & -.025 & .038 & -.072 & .979 \\
TestSc90 & .297 & .059 & -.323 & -.332 & -.401 & -.044 \\
Income90 & .008 & .185 & -.872 & .159 & .055 & .003 \\
Poverty80 & .129 & .122 & .948 & .036 & -.038 & -.031 \\
PopDen80 & .846 & -.054 & .030 & .181 & -.080 & -.070
\end{tabular}




\section{REFERENCES}

Anselin, L. Spatial Econometrics: Methods and Models. Dordrect: Kluwer Academic Publishers, 1988.

Assadian, A. "Fiscal Determinants of Migration to a Fast-Growing State: How the Aged Differ from the General Population." The Review of Regional Studies 25 No. 3 (1995): 301-316.

Barkley, D.L., and K.T. McNamara. "Manufacturers Location Decisions: Do Surveys Provide Helpful Insights." International Regional Science Review 17, No. 1 (1994): 23-48.

Berman, E., J. Bound, and Z. Griliches. "Changes in the Demand for Skilled Labor Within U.S. Manufacturing: Evidence from the Annual Survey of Manufacturers." Quarterly Journal of Economics 109 (1994): 367-396.

Betts, J. R. “Does School Quality Matter? Evidence from the National Longitudinal Survey of Youth." The Review of Economics and Statistics 77 (1995): 231 - 250. Beyers, W., E. Johnsen, and H. Stranahan."Education and Economic Development: The Producer Services." Commentary Winter (1987): 14-17.

Blair, J.P., and R. Premus. "Major Factors in Industrial Location: A Review." Economic Development Quarterly 1, No. 1 (1987): 72-85.

Boarnet, M.G. "An Empirical Model of Intrametropolitan Population and Employment Growth." Papers in Regional Science 73, No. 2 (1994): 135-152.

Broomhall, D.E., and T.E. Johnson."Economic Factors that Influence Educational Performance in Rural Schools." American Journal of Agricultural Economics 76, No. 3 (1994): 557-567.

Card, D., and A. B. Krueger. "School Resources and Student Outcomes: An Overview of the Literature and New Evidence from North and South Carolina." Working Paper 5708, 1996. National Bureau of Economic Research, Inc., Cambridge, Massachusetts.

. "Does School Quality Matter? Returns to Education and the Characteristics of Public Schools in the United States." Journal of Political Economics 100, No. 1 (1992): 1-40.

Carlin, T., and P. Ross. "Investment in Rural Education Can Mean Higher Incomes, But in Cities." Choices Fourth Quarter (1987): 22-23.

Carlino, G.A., and E.S. Mills. "The Determinants of County Growth." Journal of Regional Science 27, No. 1 (1987): 39-54.

Crihfield, J.B. "Education and Economic Development in Illinois." Policy Forum (1990), University of Illinois Institute of Government and Public Affairs, Urbana.

Erickson, R. A. "Business Climate Studies: A Critical Evaluation." Economic Development Quarterly 1, No. 1 (1987): 62-71.

Fox, W.F., H.W. Herzog, Jr., and A.M. Schlottman. “Metropolitan Fiscal Structure and Migration." Journal of Regional Science 29, No. 4 (1989): 523-536. 
Gyan-Baffour, G., and R. Shaffer. "Effects of Technical Change on Skill Requirements and Training Needs in Wisconsin," presented paper, meetings of Southern Regional Science Association, Washington, DC, April, 1993.

Griffith, D. "The Boundary Problem in Spatial Statistical Analysis." Journal of Regional Science 23 (1983): 377-87.

Hanushek, E.A. "The Economics of Schooling: Production and Efficiency in Public Schools." Journal of Economic Literature 26, No. 3 (1986): 1141-1177.

Henry, M., D. L. Barkley and S. Bao. "The Hinterland's Stake in Metropolitan Growth: Evidence from Selected Southern Regions. Journal of Regional Science 37 (1997): 479-501.

Herzog, H.W. Jr., and A.M. Schlottmann (eds.). Industry Location and Public Policy. Knoxville: The University of Tennessee Press, 1991.

Kamera, S.G. "Effect of Local Variations in Public Services on Housing Production at the Fringe of a Growth-Controlled Multi-County Metropolitan Area." Urban Studies 24 (1987): 109-117.

Killian, M.S., and T.S. Parker. "Education and Local Employment Growth in a Changing Economy." In Education and Rural Economic Development, Economic Research Service, Agriculture and Rural Economy Division, U.S. Department of Agriculture, ERS Staff Report No. AGES 9153, 1991.

Knapp, T.A., and N.E. White. "Migration Decisions and Site-Specific Attributes of Public Policy: Microeconomic Evidence from the NLSY." The Review of Regional Studies 22, No. 2 (1992): 169-184.

Knapp, T.A., and P.E. Graves. "On the Role of Amenities in Models of Migration and Regional Development." Journal of Regional Science 29, No 1 (1989): 71-87. Kraybill, D.S., and J.N. Variyan. "The Effects of Employer Size and Human Capital on Rural Wages and Employee Benefits." Southern Rural Development Series No. 170, Mississippi State University, Starkville, 1993.

Mathur, V.K., and S.H. Stein. "The Role of Amenities in a General Equilibrium Model of Regional Migration and Growth." Southern Economic Journal 59, No. 3 (1993): 394-409.

McNamara, K.T., W. Kriesel, and B. J. Deaton. "Manufacturing Location: The Impact of Human Capital Stocks and Flows." The Review of Region Studies 18, No. 1 (1988): 42-48.

Rasmussen, D.W. "Spatial Economic Development, Education, and the New Poverty." International Regional Science Review 16, No. 1 (1994): 107-117.

Renkow, M. "Explaining Income Non-Convergence: the Determinants of Earnings in Rural and Urban Areas," presented paper, American Agricultural Economics Association Meetings, San Diego, CA, 1994.

Rosenfield, S.A., E.M. Bergman, and S. Rubin. After the Factories: Changing Employment Patterns in the Rural South. Research Triangle Park, NC: Southern Growth Policies Board, 1985.

Rosenfield, S.A., E.M. Bergman, and S. Rubin. Making Connections: After the Factories Revisited. Research Triangle Park, NC: Southern Growth Policies Board, 1989. 
Sander, W. "Expenditures and Student Achievement in Illinois." Journal of Public Economics 52 (1993): 403-416.

Schaeffer, P.V., and W.H. Sander, III. "Investing in Education: Payoffs in Employment Growth." Policy Forum, University of Illinois Institute of Government and Public Affairs, Champaign-Urbana. 1, No. 1 (1988).

Schmenner, R.W., J.C. Huber, and R.L. Cook. "Geographic Differences and the Location of New Manufacturing Facilities." Journal of Urban Economics 21 (1987): 83-104.

Stallmann, J. I., and T. G. Johnson. "Community Factors in Secondary Educational Achievement in Appalachia." Youth and Society 27, No. 4 (1996): 469-484.

Teixeira, R.A., and P.L. Swain. "Skill Demand and Supply in the New Economy: Issues for Rural Areas." In Education and Rural Economic Development, Economic Research Service, Agriculture and Rural Economy Division, U.S. Department of Agriculture, ERS Staff Report No. AGES 9153, 1991.

Thurston, L., and A.M.J. Yezer. "Causality in the Suburbanization of Population and Employment." Journal of Urban Economics 35 (1994): 105-118.

Waddell, P. "Exogenous Workplace Choice in Residential Location Models: Is the Assumption Valid?" Geographical Analysis 25, No. 1 (1993): 65-82.

Word, E., C.M. Achilles, H. Bain, J. Folger, J. Johnston, N. Lintz. Project Star: Final Executive Summary Report, Kindergarten Through Third Grade. Nashville: Tennessee State Department of Education, 1990. 